\title{
SISTEM PENDUKUNG KEPUTUSAN PENERIMAAN BERAS UNTUK KELUARGA MISKIN MENGGUNAKAN METODE SIMPLE ADDITIVE WEIGHTING DI KANTOR KEPALA DESA GUMPANG
}

\author{
Deka Agus Astika1), Didik Nugroho²), Tri Irawati ${ }^{3}$ \\ 1) Program Studi Sistem Informasi, STMIK Sinar Nusantara \\ 2) Program Studi Teknik Informatika, STMIK Sinar Nusantara \\ 3) Program Studi Komputerisasi Akuntansi, STMIK Sinar Nusantara \\ 1)deka_agus@gmail.com; 2) didik_nugroho@yahoo.com; ${ }^{3)}$ irawati3@yahoo.co.id
}

\begin{abstract}
The Gumpang Village Head Office is one of the village government offices that provide both economic and social services. In the service of the village head, there is a social program that every month there is a program for poor families, which is included in certain criteria governed by the rule of government in the village head gumpang. The all citizens are entitled to get Raskin, but only for those who belong to the poor family scope and food insecurity to support his family. For that in determining the poor family (based on criteria such as: Earnings, Dependence Children, Home Conditions. Raskin program is only devoted to the poor citizens only. So as the village head is obliged to be able to select or select its citizens, to determine as the poor recipients of Raskin. Because the condition of the society is so diverse and the status of different citizens and there are various upheavals between the poor and the poor, where the citizens in the village of gumpang that look poor not necessarily poor and the citizens who look rich not necessarily rich, because citizens changed from rich to poor, poor to rich, making it difficult for village heads to determine poor families as Raskin recipients. Solution to handle the problem is to make Decision Support System used method SAW (Simple Additive Weighting). This method is chosen because this method is capable for the ranking process which will select the best alternative from a number of alternative (poor people) The technique used in this research is with Observation, Interview and literature study The design of this system is made with Context Diagram, HIPO, DAD, inter-table relation and database design. Applications are created using PHP programming languages and databases using My SQL. The old system analysis to calculate the error rate of the old system has an error rate of 1 that is the result difference between the new system with the old system is 1 riping so that the accuracy of the new system is $90 \%$. The system has been made capable of determining the poor based on many criteria resulting in more precise and comprehensive results.
\end{abstract}

Keywords: Raskin, Population, SAW, Decision Support System.

\section{PENDAHULUAN}

Kantor Kepala Desa merupakan salah satu kantor pemerintahan desa yang banyak memberikan pelayanan kemasyarakatan baik ekonomi dan sosial. Dalam pelayanannya kepala desa gumpang terdapat program sosial yaitu setiap bulannya yaitu bantuan raskin (beras miskin) program ini diberikan khusus bagi keluarga miskin, yang tidak mampu dalam perekonomian keluarga. [1]

Tidak seluruh warga masyarakat yang berhak mendapatkan Raskin, tetapi hanya bagi mereka yang tergolong dalam lingkup kelurga miskin dan rawan pangan untuk menghidupi keluarganya. sehingga diberikan batasan kuota tertentu dalam menentukan warga miskin.
Adanya batasan kuota tertentu ini dapat menyulitkan pihak kepala desa dalam menentukan warga miskin Karena kondisi masyarakat begitu beragam dan status warga yang berbeda-beda dan terdapat berbagai gejolak antara warga miskin dan kaya, dimana warga di desa gumpang yang terlihat miskin belum tentu miskin dan warga yang terlihat kaya belum tentu kaya, karena warga di desa gumpang statusya sering berubah dari kaya ke miskin, miskin ke kaya.

Solusi untuk menangani permasalahan tersebut adalah dengan membuat Sistem Pendukung Keputusan menggukan metode SAW (Simple Additive Weighting). Metode ini dipilih karena metode ini mampu untuk menentukan bobot untuk setiap kriteria, dan dilanjutkan proses perankingan yang akan 
menyeleksi alternatif terbaik dari sejumlah alternatif, dalam hal ini alternatif yang dimaksud adalah warga desa gumpang.

\section{TINJAUAN PUSTAKA}

\subsection{Keluarga Miskin}

Keluarga Miskin adalah suatu kondisi ketidakmampuan baik secara individu, keluarga, maupun kelompok sehingga kondisi ini rentan terhadap timbulnya permasalahan sosial yang lain. Kemiskinan dipandang sebagai kondisi seseorang atau sekelompok orang, laki-laki dan perempuan yang tidak terpenuhi hak-hak dasarnya secara layak untuk menempuh dan dapat mengembangkan kehidupan yang dapat bermartabat [2].

\subsection{Program Raskin}

Raskin adalah salah satu program pemerintah untuk membantu masyarakat yang miskin dan rawan pangan agar mereka mendapatkan beras untuk kebutuhan rumah tangganya. Program raskin tersebut adalah salah satu program penanggulangan kondisi kemiskinan termasuk dalam kluster I tentang bantuan perlindungan sosisal. Program Raskin merupakan program nasional yang bertujuan membantu memenuhi kecukupan pangan dan mengurangi beban finansial rumah tangga miskin (RTM) melalui penyediaan beras bersubsidi. Sejak 2007, Menteri Koordinator Kesejahteraan Rakyat menjadi koordinator pelaksanaan Program Raskin. Untuk pendistribusian beras, Bagian Badan Urusan Logistik (Bulog) bertanggung jawab mendistribusikan beras hingga titik distribusi, dan pemerintah daerah bertanggungjawab menyalurkan beras dari titik distribusi kepada RTM [3].

\subsection{SPK (Sistem Pendukung Keputusan)}

Konsep Sistem Pendukung Keputusan atau Decision Support System (DSD). Mulai pertama kali diperkenalkan oleh Michael S. Scott Morton pada awal tahun 1970-an, yang selanjutnya dikenal dengan Management Decision System. DSS merupakan sistem informasi interaktif yang menyediakan data informasi, pemodelan dan manipulasi data. Sistem ini digunakan untuk membantu dalam pengambilan keputusan dalam situasi yang semi terstruktur dan situasi yang tidak dalam terstruktur, dimana tak seorangpun tahu hasil secara pasti bagaimana dalam keputusan itu seharusnya dibuat. [4]

\subsection{Simple Additive Weighting (SAW)}

Metode SAW sering juga dikenal istilah metode penjumlahan terbobot.Konsep dasar metode SAW adalah mencari penjumlahan terbobot dari rating kinerja pada setiap alternatif pada semua atribut. Metode SAW membutuhkan proses normalisasi matriks keputusan $(X)$ ke suatu skala yang dapat diperbandingkan dengan semua rating alternatif yang ada [5].

Rumus SAW

$$
\mathrm{r}_{\mathrm{ij}}= \begin{cases}\frac{X i j}{{ }_{i}{ }_{i} X i j} & \text { Jika “j” adalah atribut } \\ \frac{\operatorname{Min}_{i} X i j}{\operatorname{Xij}_{i j}} & \text { Jika “j” adalah atribut } \\ \text { biaya (cost) }\end{cases}
$$

Keterangan :

$r_{i j} \quad$ : nilai rating kinerja ternormalisasi

$x_{i j} \quad$ : nilai atribut yang dimiliki dari setiap kriteria

$\operatorname{Max}_{\mathrm{ij}} \quad$ : nilai terbesar dari setiap kriteria

$\operatorname{Min}_{\mathrm{ij}} \quad$ : nilai terkecil dari setiap kriteria

Benefit : jika nilai terbesar adalah yang terbaik

Cost : jika nilai terkecil yang terbaik

Penelitian yang menggunakan metode ini antara lain dilakukan oleh beberapa peneliti yang bertujuan untuk pengambilan keputusan antara lain penentuan prioritas perbaikan jalan [6], sistem pendukung keputusan kelayakan pembiayaan Mikro dengan metode simple additive weighting di bank syariah mandiri KCP nusukan Surakarta [7], Sistem Pendukung Keputusan Pemilihan Hotel Di Kota Palembang Dengan Metode Simple Additive Weighting (SAW) [8], sistem pendukung keputusan penerimaan beasiswa kurang mampu SMK Harapan dengan metode Simple Additive Weighting (SAW) [9], sistem pendukung keputusan penjurusan siswa dengan metode Simple Additive Weighting (SAW)[10].

\subsection{PHP}

PHP merupakan singkatan berulang dari PHP Hypertext Preprocessor, dulu namanya Personal Home Page, pertama kali dibuat oleh Rasmus Lerdof pada tahun 1995. Fungsi yang paling populer dari PHP adalah kemampuannya sebagai server Side Programming / Scripting Language dalam pembuatan Website, atau aplikasi yang berbasis Website. Server Side Programming / Scripting adalah bahasa yang berjalan pada 
sisi server (dalam hal ini Web Server) sehingga, komputer kita (Client/Web Browser) tidak mengetahui apa yang terjadi didalam Web Server. Kita (Client/Web Browser) hanya menerima keluaran dari proses yang dihasilkan oleh Web Server.[11]

\section{6. $M y S Q L$}

MySQL merupakan salah satu produk RDBMS (Relational Database Management System) yang bisa kita nikmati secara gratis. Data yang ingin kita simpan akan digunakan RDBMS sebagai tabel-tabel yang saling berhubungan / dapat dihubungkan / maupun berdiri sendiri dalam Database. Database sendiri pada hakikatnya adalah kumpulan dari banyak tabel. SQL sendiri merupakan singkatan dari Structured Query Language, merupakan bahasa Database Standar yang digunakan pada saat ini. Dengan Query, kita bisa melakukan operasi pada Database. Misalkan, membuat tabel, mengubah tabel, menghapus, memasukan, membuat relasi tabel (menghubungkan tabel-tabel).[12]

\subsection{HIPO}

HIPO merupakan suatu desain sistem yang digunakan untuk level menyediakan penjelasan yang jelas dari input yang harus digunakan dan output yang harus dihasilkan oleh masing-masing fungsi pada tiap-tiap tingkatan dari HIPO. Bagan berjenjang untuk sistem ini terdapat proses yang dapat digambarkan sesuai dengan jenjangnya dimana jenjang tersebut terdiri dari top level, level 0 dan level 1. [11]

\subsection{ERD}

Entity Relationship Diagram (ERD) adalah model data yang menggunakan beberapa notasi untuk menggambarkan data dalam konteks entitas dan hubungan yang dideskripsikan Entity Relantionship Diagram (ERD) versi James Marthin. Pengertian dari Entity Relationship Diagram (ERD) sendiri adalah model data yang menggunakan beberapa notasi untuk menggambarkan data dalam konteks dan hubungan yang dideskripsikan oleh data tersebut. Pengertian dari ERD (Entity Relationship Diagram) adalah suatu model untuk menjelaskan hubungan antar data dalam basis data berdasarkan objek-objek dasar data yang mempunyai hubungan antar relasi [11].

\subsection{Context Diagram}

Context Diagram digunakan untuk menunjukkan atau menggambarkan arus data seluruh jaringan, masukan dan keluaran. Mengidentifikasikan awal dan akhir data, awal dan akhir yang masuk dan keluaran sistem. [11]

\section{METODE PENELITIAN}

Pada metode penelitian yang dilakukan dalam menyelesaikan penelitian ini adalah sebagai berikut:

\section{a. Metode Pengumpulan Data}

Pada metode pengumpulan data terdiri dari wawancara, observasi dan studi pustaka.

\section{b. Metode Pengembangan Sistem}

Berikut ini metode dalam Pengembangan sistem yaitu analisa system, perancangan system (Contex Diagram, HIPO, DAD), Desain Sistem (desain input, desain output, desain teknologi dan desain database). Implementasi Sistem, Pengujian Sistem (uji fungsionalitas dan uji validitas).

\section{HASIL DAN PEMBAHASAN \\ 4.1 Kriteria dan Bobot}

Pada metode Simple Addictive Wighting (SAW) terdapat kriteria dan bobot yang dibutuhkan untuk menentukan karyawan berpretasi seperti dalam Tabel 1 dan Tabel 2 berikut.

Tabel 1 Kriteria

\begin{tabular}{|c|l|}
\hline Kriteria & \multicolumn{1}{|c|}{ Keterangan } \\
\hline K1 & Penghasilan \\
\hline K2 & Tanggunan Anak \\
\hline K3 & Kondisi Rumah \\
\hline
\end{tabular}

Tabel 2 Nilai Bobot

\begin{tabular}{|l|c|}
\hline \multicolumn{1}{|c|}{ Kriteria } & Bobot \\
\hline Penghasilan (K1) & 10 \\
\hline Tanggunan Anak (K2) & 5 \\
\hline Kondisi Rumah (K3) & 7.5 \\
\hline
\end{tabular}

Adapun penjelasan dari masing-masing kriteria pada sistem pendukung keputusan penerimaan raskin adalah sebagai berikut.

1. Penghasilan

Nilai Penghasilan termasuk jenis cost. artinya semakin rendah jumlah penghasilan maka nilai semakin tinggi, hal ini dapat dilihat pada Tabel 3 berikut. 
Tabel 3 Kriteria Penghasilan

\begin{tabular}{|c|l|c|}
\hline Penghasilan (K1) & \multicolumn{1}{|c|}{ Bilangan Fuzzy } & Nilai \\
\hline $\mathrm{K} 2<=1.000 .000$ & Rendah (R) & 2,5 \\
\hline $1.000 .000<\mathrm{K} 2<=3.000 .000$ & Sedang (S) & 5 \\
\hline $3.000 .000<\mathrm{K} 2<=5.000 .000$ & Tinggi (T) & 7,5 \\
\hline $\mathrm{K} 2>5.000 .000$ & Sangat Tinggi (ST) & 10 \\
\hline $\mathrm{K} 2<=1.000 .000$ & Rendah (R) & 2,5 \\
\hline
\end{tabular}

\section{Tanggungan Anak}

Kriteria tanggungan anak termasuk kriteria benefit. artinya semakin tinggi jumlah dana penghasilan maka nilai semakin tinggi, hal ini dapat dilihat pada Tabel 4 berikut.

Tabel 4 Kriteria Tanggungan Anak

\begin{tabular}{|l|l|l|}
\hline Tanggunan Anak (K2) & Bilangan Fuzzy & Nilai \\
\hline $\mathrm{K} 3=1$ anak & Sangat Rendah (SR) & 2 \\
\hline $\mathrm{K} 3=2$ anak & Rendah $(\mathrm{R})$ & 4 \\
\hline $\mathrm{K} 3=3$ anak & Sedang (S) & 6 \\
\hline $\mathrm{K} 3=4$ anak & Tinggi (T) & 8 \\
\hline $\mathrm{K} 3>=5$ anak & Sangat Tinggi (ST) & 10 \\
\hline
\end{tabular}

3. Kondisi Rumah

Kriteria kondisi rumah adalah termasuk kriteria cost. artinya semakin rendah jenis kondisi rumah maka nilai semakin tinggi, hal ini dapat dilihat pada Tabel 5.

Tabel 5 Kondisi Rumah

\begin{tabular}{|l|l|c|}
\hline \multicolumn{1}{|c|}{ Tanggungan Anak (K3) } & Bilangan Fuzzy & Nilai \\
\hline Cukup Sederhana & Rendah (R) & 2,5 \\
\hline Sederhana & Sedang (S) & 5 \\
\hline Mewah & Tinggi (T) & 7,5 \\
\hline Sangat Mewah & Sangat Tinggi (ST) & 10 \\
\hline
\end{tabular}

\subsection{Perancangan Sistem}

Perancangan sistem merupakan suatu desain rancangan sistem yang dibuat untuk menggambarkan alur jalannya suatu sistem. Berikut tahapan dalam perancangan sistem

\section{Contex Diagram}

Contex Diagram (CD) untuk sistem pendukung keputusan penerimaan Raskin di Desa Gumpang adalah hal ini dapat dilihat pada Gambar 1 berikut.

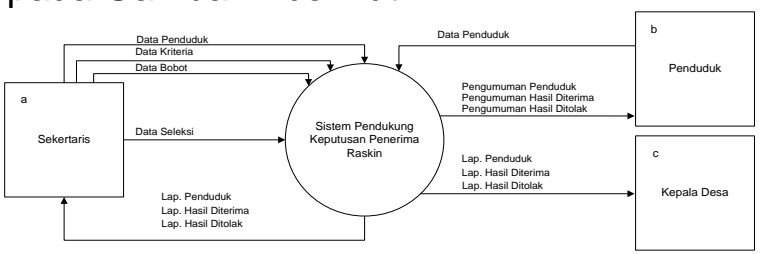

\section{2. $\mathrm{HIPO}$}

\section{Gambar 1. Context Diagram}

HIPO (Hierarki Input Process Output) untuk system Pendukung Keputusan penerimaan Raskin di Desa Gumpang seperti dalam Gambar 2.

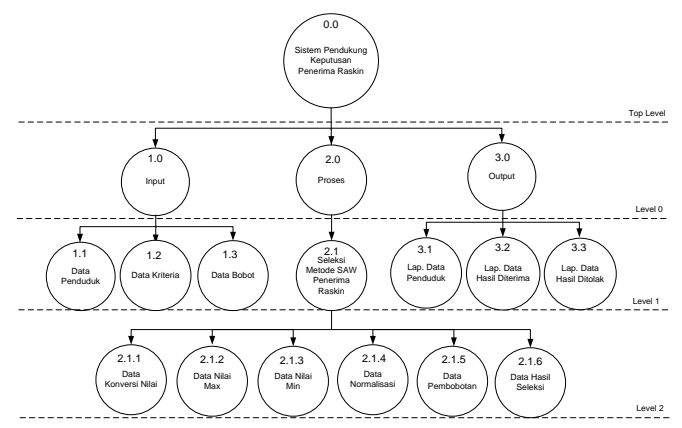

Gambar 2. HIPO SPK Penerimaan Raskin

3. $D A D$

Diagram Arus Data (DAD) level 0 untuk SPK Peneriman Raskin di Desa Gumpang seperti dalam gambar 3 berikut :

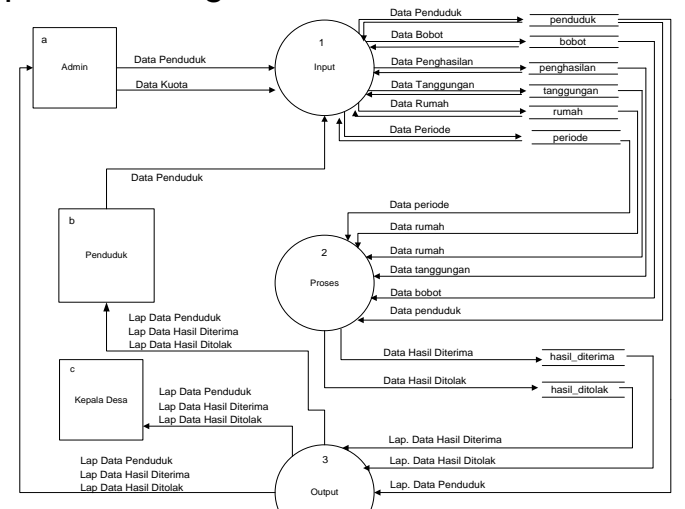

Gambar 3. DAD Level 0

\section{ERD (Entity Relation Diagram)}

Entity Relationship Diagram pada sistem pendukung keputusan penerimaan Raskin di Desa Gumpang seperti dalam Gambar 4.

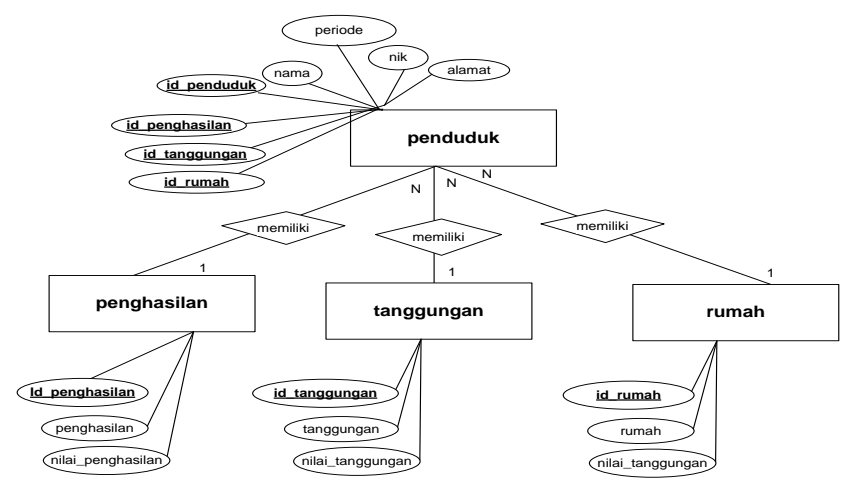

Gambar 4. ERD (Entity Relationship Diagram)

\subsection{Implementasi Sistem}

Implementasi sistem merupakan proses pembuatan sistem berupa perancangan aplikasi SPK Penerimaan Raskin. 


\section{Input data penduduk}

Tampilan input data yang digunakan untuk menginput data penduduk di desa gumpang seperti dalam Gambar 5 berikut.

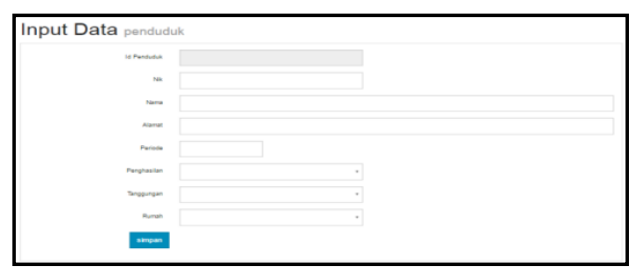

Gambar 5. Form Input Data Penduduk

\section{Proses Seleksi}

Tampilan Menu Proses Seleksi untuk menentukan penerima raskin berdasarkan jumlah kuota yang telah ditentukan seperti dalam Gambar 6 berikut.

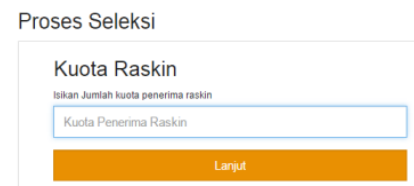

\section{Gambar 6. Menu Proses Seleksi}

\section{Tampilan Laporan}

Tampilan hasil laporan SPK penerimaan raskin dibuat 3 jenis yaitu laporan data penduduk, laporan hasil seleksi diterima dan laporan hasil seleksi ditolak. Berikut ini adalah tampilan dari ketiga jenis laporan akhir dari hasil proses seleksi sistem. Hasil laporan ini dapat dilihat dalam Gambar 7, 8, 9 dan 10 berikut :

a. Laporan Data Penduduk

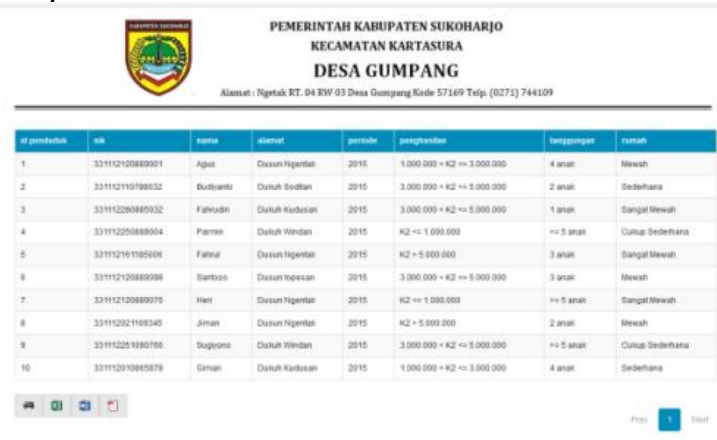

Gambar 7. Laporan Data Penduduk

b. Laporan Diterima

Laporan Hasil Diterima

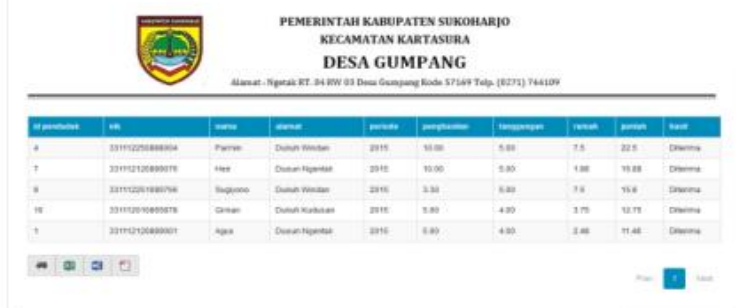

Gambar 8. Laporan Hasil Diterima c. Laporan Hasil Di Tolak

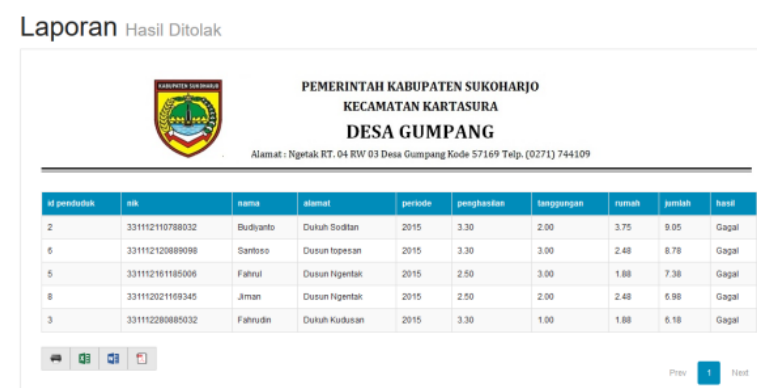

Gambar 9. Laporan Hasil Di Tolak

\subsection{Pengujian Sistem}

Pengujian merupakan proses uji sistem pada bagian akhir yang juga berguna untuk mengetes sistem. ada dua pengujian sistem yaitu uji fungsionalitas dan uji validitas.

\subsubsection{Pengujian Fungsionalitas}

Pengujian fungsionalitas menggunakan Black Box, yang berguna untuk mengetahui hasil output dalam setiap form disistem program. Hasil pengujian dapat dilihat pada Tabel 6 berikut:

\section{Tabel 6. Uji Fungsionalitas}

\begin{tabular}{|c|c|c|c|c|c|c|c|}
\hline No & Jenis $\mathrm{Uji}$ & $\begin{array}{c}\text { Komponen } \\
\text { Sistem } \\
\text { yang diuji }\end{array}$ & Skenario $\mathrm{Uji}$ & $\begin{array}{l}\text { Hasil yang } \\
\text { diharaplkan }\end{array}$ & Hasil yang dihasilian & $\begin{array}{c}\text { Satus } \\
\text { Ujij }\end{array}$ & $\begin{array}{c}\text { Hasil } \\
\text { Pengujian }\end{array}$ \\
\hline \multirow{2}{*}{1} & Uji Nomal & $\begin{array}{l}\text { Form Login } \\
\text { Admin }\end{array}$ & 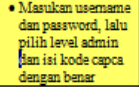 & $\begin{array}{l}\text { - Tampil } \\
\text { halaman } \\
\text { manur utama } \\
\text { admin } \\
\end{array}$ & $\begin{array}{l}\text { - Muncul pesan "Login } \\
\text { Sulkses, Selamat } \\
\text { Dastagn adinin" } \\
\text { - Tampil halaman admin }\end{array}$ & Nomal & Diterima \\
\hline & Uji Salah & $\begin{array}{l}\text { Form Login } \\
\text { Admin }\end{array}$ & $\begin{array}{l}\text { - Masulkan usemame } \\
\text { dan password, lalu } \\
\text { pilih level admin } \\
\text { dan is kisode capca } \\
\text { dangan aslah }\end{array}$ & $\begin{array}{c}\text { - Muncul } \\
\text { pasan } \\
\text { keasalahan }\end{array}$ & $\begin{array}{l}\text { - Muncul pasan "Code } \\
\text { Salah!" } \\
\text { - Tidak masuk admin }\end{array}$ & Nomal & Diterims \\
\hline \multirow[t]{2}{*}{2} & Uji Nomal & $\begin{array}{l}\text { Form Irput } \\
\text { Data Admin }\end{array}$ & $\begin{array}{l}\text { - Masulkan data } \\
\text { admin secara } \\
\text { lenglkap den benar }\end{array}$ & $\begin{array}{l}\text { - Data } \\
\text { tersimpan } \\
\text { dengan baik } \\
\text { dan benar }\end{array}$ & $\begin{array}{l}\text { - Murcul pasan } \\
\text { "Penyimpanan } \\
\text { Berhasil" } \\
\text { - Tersimpan dengan baik }\end{array}$ & Nomal & Diterima \\
\hline & Uji Salah & $\begin{array}{l}\text { Form Input } \\
\text { Dasta Admin }\end{array}$ & $\begin{array}{l}\text { - Masulkan data } \\
\text { admin secrata tidal: } \\
\text { lenglkapp }\end{array}$ & $\begin{array}{c}\text { - Tidalk bisa } \\
\text { menyimpen }\end{array}$ & - Tidalk bisa disimpen & Normal & Diterima \\
\hline \multirow{2}{*}{3} & Uji Nomal & $\begin{array}{l}\text { Form Input } \\
\text { Data } \\
\text { Pendudull }\end{array}$ & $\begin{array}{l}\text { - Masukan data } \\
\text { penduduluk secara } \\
\text { lenglapp dan benar }\end{array}$ & $\begin{array}{l}\text { - Dasta debitur } \\
\text { tersimpan } \\
\text { dengan baik } \\
\text { dan benar }\end{array}$ & $\begin{array}{l}\text { - Muncul pesan } \\
\text { "Penyimpanan } \\
\text { Berhasil" } \\
\text { - Tersimpan dengan beilk }\end{array}$ & Nomal & Diterima \\
\hline & Uji Salah & $\begin{array}{l}\text { Fom Input } \\
\text { Data } \\
\text { Pandudull }\end{array}$ & $\begin{array}{l}\text { - Masulkan data } \\
\text { penduduk secara } \\
\text { tidak lenglkap }\end{array}$ & $\begin{array}{c}\text { - Tidalk bisa } \\
\text { manyimpan }\end{array}$ & -Tidakk bisa disimpan & Nomal & Diterima \\
\hline \multirow[t]{2}{*}{4} & Uji Nomal & $\begin{array}{l}\text { Form Input } \\
\text { Bobot }\end{array}$ & $\begin{array}{l}\text { - Masulkan data } \\
\text { bobbot tecara } \\
\text { lenglkap des benar }\end{array}$ & $\begin{array}{l}\text { - Dasta kelas } \\
\text { tersimpan } \\
\text { dengan baik } \\
\text { den benar } \\
\end{array}$ & $\begin{array}{l}\text { - Murcul pasan } \\
\text { "Penyimpanan } \\
\text { Berhasil" } \\
\text { - Tersimpan dengan bejik }\end{array}$ & Nomal & Diterima \\
\hline & Uji Salah & $\begin{array}{l}\text { Form Input } \\
\text { Bobot }\end{array}$ & $\begin{array}{l}\text { - Masukan data } \\
\text { bobot secara tidak } \\
\text { lenglegp }\end{array}$ & $\begin{array}{c}\text { - Tidalk bisa } \\
\text { manyimpan }\end{array}$ & - Tidalk bisa disimpan & Nomal & Diterima \\
\hline \multirow{2}{*}{6} & Uji Nomal & $\begin{array}{l}\text { Form Input } \\
\text { Kriteria } \\
\text { Penghasilan }\end{array}$ & 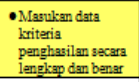 & $\begin{array}{l}\text { Datak kelas } \\
\text { tersimpan } \\
\text { dengan baik } \\
\text { dan benar } \\
\end{array}$ & $\begin{array}{l}\text { - Muncul pesan } \\
\text { "Penyimpanan } \\
\text { Berhasil" } \\
\text { - Tersimpan dengan baik }\end{array}$ & Nomal & Diterima \\
\hline & Uji Salah & $\begin{array}{l}\text { Form Input } \\
\text { Kriteris } \\
\text { Penghasilan }\end{array}$ & 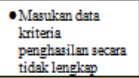 & $\begin{array}{l}\text { - Tidalk bisa } \\
\text { menyimpan }\end{array}$ & - Tidalk bisa disimpan & Nomal & Diterima \\
\hline \multirow[t]{2}{*}{7} & Uji Nomal & $\begin{array}{l}\text { Fomm Irput } \\
\text { Kriteria } \\
\text { Tanggungan }\end{array}$ & 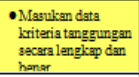 & $\begin{array}{l}\text { - Dats kelas } \\
\text { tersimpan } \\
\text { dengan beik } \\
\text { dan hanar }\end{array}$ & $\begin{array}{l}\text { - Muncul pesan } \\
\text { "Penyimpanan } \\
\text { Berhasil" } \\
\text { - Tersimonan dengan baik }\end{array}$ & Nomal & Diterims \\
\hline & Uji Salah & $\begin{array}{l}\text { Fomm Input } \\
\text { Kriteria } \\
\text { Tanggungan }\end{array}$ & 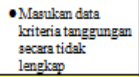 & $\begin{array}{l}\text { - Tidalk bisa } \\
\text { manyimpan }\end{array}$ & - Tidalk bisa disimpan & Nomal & Diterima \\
\hline \multirow{2}{*}{8} & Uji Nomal & $\begin{array}{l}\text { Form Input } \\
\text { Kriteria } \\
\text { Rumah }\end{array}$ & $\begin{array}{l}\text { - Masulkan data } \\
\text { kriteria numah } \\
\text { secaral englisp dan } \\
\text { benar }\end{array}$ & $\begin{array}{l}\text { - Data kelas } \\
\text { tersimpan } \\
\text { dengan beik } \\
\text { den benar }\end{array}$ & $\begin{array}{l}\text { - Murcul pasan } \\
\text { "Penyimpanan } \\
\text { Berhasil" } \\
\text { - Tersimpan dengan baik }\end{array}$ & Nomal & Diterima \\
\hline & Uji Salah & $\begin{array}{l}\text { Fom Input } \\
\text { Kriteria } \\
\text { Rumah }\end{array}$ & $\begin{array}{l}\text { - Masulkan data } \\
\text { karierian numah } \\
\text { gecara tidal: } \\
\text { lenglagp }\end{array}$ & $\begin{array}{l}\text { - Tidalk bisa } \\
\text { menyimpan }\end{array}$ & - Tidalk bisa disimpan & Nomal & Diterima \\
\hline \multirow[t]{2}{*}{9} & Uji Nomal & $\begin{array}{l}\text { Form Input } \\
\text { Kuota }\end{array}$ & $\begin{array}{l}\text { - Masulkan data } \\
\text { kuota sacaras } \\
\text { lenglkap dan benar }\end{array}$ & $\begin{array}{l}\text { - Data kelas } \\
\text { tersimpan } \\
\text { dengan baik } \\
\text { den benar } \\
\end{array}$ & $\begin{array}{l}\text { - Muncul pesan } \\
\text { "Penyimpanan } \\
\text { Berhasil" } \\
\text { - Tersimpan dengan baik }\end{array}$ & Nomal & Diterima \\
\hline & Uji Salah & $\begin{array}{l}\text { Form Input } \\
\text { Kuota }\end{array}$ & $\begin{array}{l}\text { - Masulkan data } \\
\text { knota secara tidal: }\end{array}$ & $\begin{array}{c}\text { - Tidalk bisa } \\
\text { menyimpen }\end{array}$ & - Tidakk bisa disimpan & Nomal & Diterima \\
\hline
\end{tabular}




\subsubsection{Pengujian Validitas}

Uji validitas adalah membandingkan antara hasil perhitungan manual dengan hasil komputerisasi. berikut ini perhitungan manual metode SAW.

\section{Menentukan Data Penduduk}

Tahap pertama yang dipersiapkan data penduduk di desa Gumpang dalam Tabel 7 berikut.

Tabel 7. Data Penduduk

\begin{tabular}{|c|c|c|c|c|c|c|c|}
\hline ID & NIK & Nama & Alamat & Periode & Penghasilan & Tanggungan & Rumah \\
\hline 1 & 331112120889001 & \begin{tabular}{|l|} 
Aggus \\
\end{tabular} & Dsn. Ngentak & 2015 & Rp. 1500.000 & \begin{tabular}{|l|l|}
4 anak \\
\end{tabular} & Mewah \\
\hline 2 & 331112110788032 & \begin{tabular}{|l|} 
Budiyanto \\
\end{tabular} & Dukuh soditan & 2015 & Rp. 3400.000 & 2 anak & Sederhana \\
\hline 3 & 331112280885032 & \begin{tabular}{|l|} 
Fahrudin \\
\end{tabular} & Dukuh Kudusan & 2015 & Rp. 4500.000 & 1 ansk & \begin{tabular}{|l} 
Sangat Mewah \\
\end{tabular} \\
\hline 4 & 331112250888004 & \begin{tabular}{|l|} 
Parmin \\
\end{tabular} & Dukuh windan & 2015 & Rp. 800.000 & $y=5$ anak & Cukup Sederhang \\
\hline 5 & 331112161185006 & \begin{tabular}{|l|} 
Fahrul \\
\end{tabular} & Dusun Ngentak & 2015 & Rp. 6000.000 & 3 anak & Sangat Mewah \\
\hline 6 & 331112120889098 & Santoso & Dusun Topessn & 2015 & Rp. 4500.000 & 3 anak & Mewah \\
\hline 7 & 331112120889076 & Heri & Dusun Ngentak & 2015 & Rp. 950.000 & $y=5$ anak & Sangat Mewah \\
\hline 8 & 331112021169345 & Jiman & Dusun Ngentak & 2015 & Rp. 6000.000 & 2 anak & \begin{tabular}{|l|} 
Mewah \\
\end{tabular} \\
\hline 9 & 331112251090766 & \begin{tabular}{|l|} 
Sugiyono \\
\end{tabular} & Dukuh windan & 2015 & $\begin{array}{l}\text { Rp. } 4500.000 \\
\end{array}$ & $y=5$ anak & Cukup Sederhna \\
\hline 10 & 331112010865878 & Giman & Dukuh Kudusan & 2015 & Rp.2000.000 & 4 anak & Sederhana \\
\hline
\end{tabular}

\section{Konversi nilai}

Dalam melakukan konversi nilai maka diperlukan aturan pada kriteria, agar diperloh data nilai yang tepat. Berikut ini hasil konversi nilai berdasarkan tabel kriteria penjelasan diatas. Hasil perhitungan dalam Tabel 8 berikut.

\section{Tabel 8. Data Konversi Nilai}

\begin{tabular}{|c|c|c|c|}
\hline ID & K1 & K2 & K3 \\
\hline 1 & 5 & 8 & 7,5 \\
\hline 2 & 7,5 & 4 & 5 \\
\hline 3 & 7,5 & 2 & 10 \\
\hline 4 & 2,5 & 10 & 2,5 \\
\hline 5 & 10 & 6 & 10 \\
\hline 6 & 7,5 & 6 & 7,5 \\
\hline 7 & 2,5 & 10 & 10 \\
\hline 8 & 10 & 4 & 7,5 \\
\hline 9 & 7,5 & 10 & 2,5 \\
\hline 10 & 5 & 8 & 5 \\
\hline
\end{tabular}

3. Normalisasi

Dalam melakukan proses normalisasi dibuat kedalam bentuk matrik $X$ sebagai berikut :

$$
X=\left\{\begin{array}{ccc}
0,5 & 0,8 & 0,33 \\
0,33 & 0,4 & 0,5 \\
0,33 & 0,2 & 0,25 \\
1 & 1 & 1 \\
0,25 & 0,6 & 0,25 \\
0,33 & 0,6 & 0,33 \\
1 & 1 & 0,25 \\
0,25 & 0,4 & 0,33 \\
0,33 & 1 & 1 \\
0,5 & 0,8 & 0,5
\end{array}\right\}
$$

4. Perangkingan

Berikut ini proses perangkingan pada metode SAW adalah sebagai berikut :

$$
\begin{aligned}
& \text { V1 }=\left(10^{\star} 0.5\right)+\left(5^{\star} 0.8\right)+\left(7.5^{\star} 0.33\right)=11.48 \\
& \text { V2 }=\left(10^{\star} 0.33\right)+\left(5^{\star} 0.4\right)+\left(7.5^{\star} 0.5\right)=9.08 \\
& \text { V3 }=\left(10^{\star} 0.33\right)+\left(5^{\star} 0.2\right)+\left(7.5^{\star} 0.25\right)=6.21 \\
& \text { V4 }=\left(10^{\star} 1\right)+\left(5^{\star} 1\right)+\left(7.5^{\star} 1\right)=22.50 \\
& \text { V5 }=\left(10^{\star} 0.25\right)+\left(5^{\star} 0.6\right)+\left(7.5^{\star} 0.25\right)=7.38 \\
& \text { V6 }=\left(10^{\star} 0.33\right)+\left(5^{\star} 0.6\right)+\left(7.5^{\star} 0.33\right)=8.83 \\
& \text { V7 }=\left(10^{\star} 1\right)+\left(5^{\star} 1\right)+\left(7.5^{\star} 0.25\right)=16.875 \\
& \text { V8 }=\left(10^{\star} 0.25\right)+\left(5^{\star} 0.4\right)+\left(7.5^{\star} 0.33\right)=6.81 \\
& \text { V9 }=\left(10^{*} 0.33\right)+\left(5^{\star} 1\right)+\left(7.5^{\star} 1\right)=15.83 \\
& \text { V10 }=\left(10^{*} 0.5\right)+\left(5^{\star} 0.8\right)+\left(7.5^{\star} 0.5\right)=12.75
\end{aligned}
$$

Dari proses perhitungan diatas kemudian dilakukan perangkingan dapat dilihat dalam Tabel 9 berikut.

Tabel 9. Hasil Perangkingan

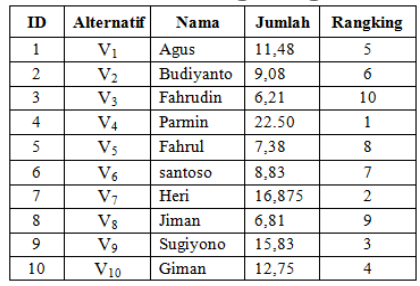

Berdasarkan hasil perhitungan diatas kemudian diseleksi berdasarkan jumlah kuota yaitu pada Tabel 10 dan Tabel 11.

Tabel 10. Hasil Diterima

\begin{tabular}{|c|c|c|l|l|c|}
\hline No & ID & Alternatif & Nama & Jumlah & Ringking \\
\hline 1 & 4 & $\mathrm{~V}_{4}$ & Parmin & 22,50 & 1 \\
\hline 2 & 7 & $\mathrm{~V}_{7}$ & Heri & 16,875 & 2 \\
\hline 3 & 9 & $\mathrm{~V}_{9}$ & Sugiyono & 15,83 & 3 \\
\hline 4 & 10 & $\mathrm{~V}_{10}$ & Giman & 12,75 & 4 \\
\hline 5 & 1 & $\mathrm{~V}_{1}$ & Agus & 11,48 & 5 \\
\hline
\end{tabular}

Tabel 11 Hasil Ditolak

\begin{tabular}{|c|c|c|c|c|c|}
\hline No & ID & Alternatif & Nama & Jumlah & Ringking \\
\hline 1 & 2 & $\mathrm{~V}_{2}$ & Budiyanto & 9,08 & 6 \\
\hline 2 & 6 & $\mathrm{~V}_{6}$ & Santoso & 8,83 & 7 \\
\hline 3 & 5 & $\mathrm{~V}_{5}$ & Fahrul & 7,83 & 8 \\
\hline 4 & 8 & $\mathrm{~V}_{8}$ & Jiman & 6,81 & 9 \\
\hline 5 & 3 & $\mathrm{~V}_{3}$ & Fahrudin & 6,21 & 10 \\
\hline
\end{tabular}

\section{b. Hasil Hitungan di Program}

Berikut ini hasil seleksi keseluruhan pada sistem baru di program dalam Gambar 10 berikut.

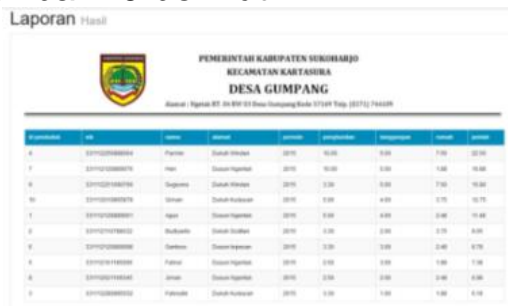

\section{Gambar 10. Hasil Keseluruhan}

Dari hasil seleksi datas kemudian diambil data diterima atau ditolak sebanyak kuota yang ditentukan. Hasil seleksi dapat dilihat pada Gambar 11 berikut. 


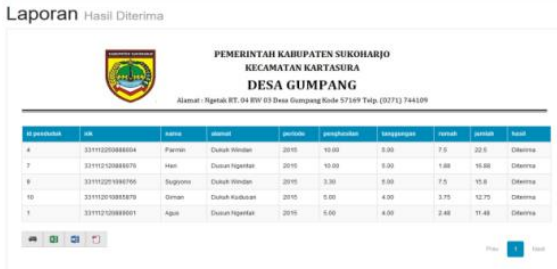

Gambar 11. Hasil Seleksi Diterima

Berikut ini adalah hasil seleksi data ditolak dapat dilihat dalam Gambar 12 berikut.

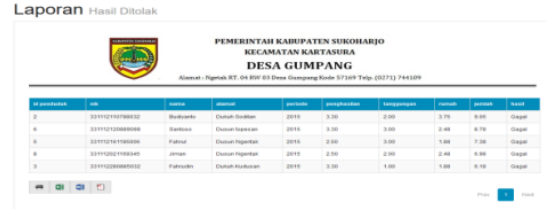

Gambar 12. Hasil Seleksi Ditolak

\section{Ringkasan Manual Dengan Program}

Berdasarkan proses perhitungan diatas maka diperoleh hasil ringkasan dalam perhitungan manual vs program dapat dilihat pada Gambar 13 berikut.

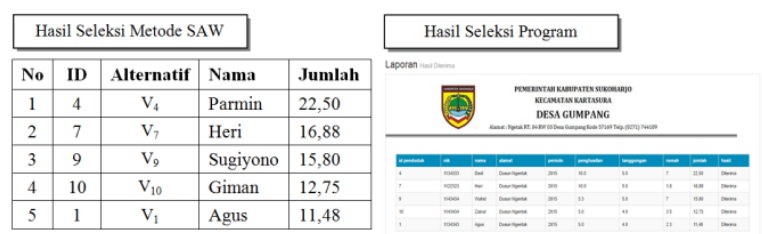

\section{Gambar 13. Perbandingan Manual Dengan Program}

Berdasarkan hasil perbandingan antara perhitungan manual vs program, terlihat bahwa hasil total menunjukan nilai yang sama. Maka dengan demikian dinyatakan bahwa program yang telah dibuat telah sesui dengan hasil perhitungan manual algoritma SAW. Sehingga dinyatakan sistem program Aplikasi Sistem Pendukung Keputusan Penerimaan Raskin ini telah layak untuk digunakan dan dinyatakan valid, karena hasil uji validitas menyatakan nilai uji manual dan program adalah sama hasilnya.

Analisa sistem lama untuk menghitung tingkat kesalahan sistem lama penulis menggunakan perhitungan

$$
\begin{aligned}
& \text { Percentage Error }= \\
& \frac{\text { Sistem Baru-Sistem Lam a }}{\text { Jumla h Data }} \times 100 \% \\
& \text { Percentage Error }=\frac{10-1}{10} \times 100 \%=90 \%
\end{aligned}
$$

maka didapatkan hasil perhitungan seleksi menggunakan sistem lama mempunyai tingkat kesalahan sebesar 1 yaitu selisih hasil antara system baru dengan sistem lama adalah 1 rangking sehingga diperloleh akurasi pada sistem baru adalah $90 \%$.

\section{PENUTUP}

\subsection{Kesimpulan}

Berdasarkan hasil pembahasan yang telah dilakukan maka kesimpulannya sebagai berikut :

1. Terbentuknya Suatu Sistem Pendukung Keputusan dengan Menggunakan Metode SAW (Simple Additive Weighting) Di Kantor Kepala Desa Gumpang.

2. Hasil tingkat pengujian sistem dengan uji validitas diperloleh akurasi sebesar $90 \%$

3. Sistem baru menggunakan Metode Simple Additive Weighting yang mampu menerapkan beberapa kriteria seperti Penghasilan, Tanggungan Anak dan Kondisi Rumah sehingga mampu menentukan alternatif terbaik (warga miskin) yang berhak menerima Raskin.

\subsection{Saran}

Adapun saran-saran dari penelitian ini adalah sebagai berikut :

1. Program Aplikasi Sistem Pendukung Keputusan ini masih terdapat kekurangan pada import data yaitu belum mampu import data dari file excel, sehingga untuk pembaca yang ingin mengembangkan aplikasi ini bisa ditambahkan menu import file excel sehingga bisa mempercepat pengisian data.

2. Aplikasi ini terbatas pada kriteria tertentu dan belum terdapat adanya menu untuk penambahan kriteria, semoga pembaca bisa mengembangkan aplikasi ini dengan menambahan menu kriteria sehingga membantu dalam proses seleksi sistem.

3. Program SPK yang telah dibuat masih cukup sederhana karena lebih mengutamakan inti dari proses perhitungan metode SAW.

4. Gunakanlah program Aplikasi Sistem Pendukung Keputusan Penerima Raskin ini dengan baik yaitu sesuai dengan aturannya.

\section{DAFTAR PUSTAKA}

[1] Alhamdi, Program Keluarga Miskin dan Peran Kerja Keluarga Miskin Sosial. Yogyakarta: PT. Saliondo, 2012.

[2] Andi, Desain Sistem Informasi dan Diagram Arus Sistem. Jakarta: Cahya Hnedra Teguh, Prenhelindo, 2012.

[3] D. Suprianto, Buku Pintar Pemrograman PHP. Bandung: OASE Media, 2012. 
[4] E. Turban dan J. E. Aronson, Decision Support Systems and Intelligent Systems 6th Edistion. NJ: Prentice Hall Upper Saddle River, 2012.

[5] S. Kusumadewi, S. Hartati, and A. Harjoko, Fuzzy Multi Attribute Decision Making (FUZZY MADM). Yogyakarta: Graha Ilmu, 2006.

[6] M. Muhammad and N. P. Novi Safriadi, "Implementasi Metode Simple Additive Weighting ( SAW ) Pada Sistem Pendukung Keputusan Dalam Menentukan Prioritas Perbaikan Jalan," J. Media Inform. Budidarma ISSN 25488368, vol. 5, no. 2, pp. 49-53, 2017.

[7] A. Y. Ardiyan, W. L. Y. Saptomo, and M. Hasbi, "Sistem Pendukung Keputusan Pembiayaan Mikro Dengan Metode Simple Additive Weighting Di Bank." Jurnal Teknologi Informasi dan Komunikasi (TIKomSiN) Vol. 3, No. 2, 2015

[8] D. C. Hartini, E. L. Ruskan, and A. Ibrahim, "Sistem Pendukung Keputusan Pemilihan Hotel Di Kota Palembang Dengan Metode Simple Additive Weighting (SAW)," J. Sist. Inf., vol. 5, no. 1, pp. 546-565, 2013.

[9] A. W. Pamungkas, D. Nugroho, and S. Siswanti, "Penerimaan Beasiswa Kurang Mampu SMK Harapan Dengan Metode Simple Additive Weighting ( Saw )," TIKomSiN, vol. 4, pp. 35-41, 2016.

[10] W. L. Y. Saptomo and S. Siswanti, "Sistem Pendukung Keputusan Penjurusan Siswa Dengan Metode Simple Additive Weighting ( SAW )," J. IIm. SINUS, Vol. 12, No., pp. 45-56, 2014.

[11] Jogiyanto, Analisis dan Desain Sistem Informasi, Edisi IV. Yogyakarta: Andi Offset, 2011.

[12] Kendal, Analisis Perkembangan Diagram Konteks dan desain Sistem. Yogyakarta: Penerbit Xsos, 2013. 